\title{
A recipe for Policy research in AYUSH educational and research programs
}

\author{
Kalyan Maity ${ }^{1}$, Vijaya Majumdar ${ }^{1}$, Amit Singh ${ }^{1}$, Akshay Anand $^{2 *}$ \\ Division of Yoga and Life Sciences, Swami Vivekananda Yoga Anusandhana Samsthana (S-VYASA), Bengaluru, Karnataka, India ${ }^{1}$ \\ Neuroscience Research Lab, Department of Neurology, PGIMER, Chandigarh, India ${ }^{2}$
}

\section{KEY WORDS}

\section{Ayush}

Integrative health

Yoga

Research
${ }^{*}$ Corresponding Author:

Akshay Anand, PhD

Professor, Neuroscience Research Lab

Department of Neurology, PGIMER, Chandigarh, India

Contact no: +91-9914209090

E-mail: akshay1anand@rediffmail.com
Yoga, Ayurveda, and Siddha represent the ancient science of healthy living originated in India. Some of the oldest texts from around 5000 years back, such as Vedas and Upanishads, provide evidence of such lifestyle. Many seals and fossils from Indus Valley Civilization authenticate the practice of Yoga in ancient India. According to yogic tradition, Shiva, one of the Hindu Gods, is the first yogi (Adi yogi) and the first teacher (Adi Guru). The meticulous practice of Yoga is widely believed to play a major role to overcome mental and physical suffering and leads to self-regulation, and finally to self-realization or liberation. Since the Pre-Vedic period around 2700 B.C., people started practicing Yoga. Later on, Patanjali Maharshi (between $3^{\text {rd }}$ to $6^{\text {th }}$ centuries BC) systematized and codified knowledge of Yoga through his Yoga Sutras. Later, with the help of many sages and masters, Yoga spread through different traditions, lineages and Guru-shishya parampara. Various Yoga schools viz. Jnana, Bhakti, Karma, Raja, Dhyana, Patanjali, Kundalini, Hatha, Laya, Jain, Buddha, Hatha etc. which follow their own practice, principles and tradition. However, they all lead to the same goal. The history of modern Yoga started in 1893 when the Parliament of Religions was held. After that many yogacharya, teachers and practitioners tried to spread Yoga, not only in India but worldwide (1). One of the milestones in the history of Yoga has been the adoption of the International Day of Yoga. The Honorable Prime Minister Sri Narendra Modi addressed the world community on $27^{\text {th }}$ September 2014 in 69 sessions of the United Nations General Assembly (UNGA) (2). The proposal was approved on $11^{\text {th }}$ December 2014 by 193 members of UNGA to establish
21 June as "International Day of Yoga". Six months later after passing the resolution and confirmation to establish IDY, the first IDY held in 2015. Several Yogic events were organized and publicized throughout India as well as abroad and got national and international publicity that Yoga has originated from Indian culture. The essential and pivotal role of Yoga in education, pedagogy, curriculum, as well as clinical research has been realized well across the globe (3). To achieve the same, AYUSH Ministry was established November 9, 2014 (http:// ayush.gov.in) to facilitate research and educational activity in Ayurveda, Yoga and Naturopathy, Unani, Siddha and Homoeopathy. The existence and excellence of Yoga-based researches in the premier Institutes of India is another milestone towards the implementation of yogic sciences in the academic sphere. Several Yoga departments and centers in the premier Institutes and central universities of India, their existence and establishment, is the result of the consultative meeting on Yoga Education in Universities held in Bangalore on $2^{\text {nd }}$ January 2016, chaired by the Hon'ble Minister for Human Resource Development in the presence of Vice-Chancellors from Indian universities. It was resolved to set up a Department of Yogic Art and Science in the Universities and constitute a committee on Yoga Education in universities to look into various aspects pertaining to setting up of these Departments. Further, collaborative efforts were made to support Psychology, Philosophy, and Yogic Science at different collaborating organizations, by utilizing their respective expertise, knowledge, resources and infrastructure (https://www.nhp.gov.in/list-of-yogainstitutes_mtl). The aim of such centers was to understand 
deeper knowledge of Yoga philosophy and Yoga therapy based on classical Yogic texts. For the last several years, S-VYASA University has been doing research on evidence-based Yoga $\&$ its application, to prevent diseases and to promote positive health (https://svyasa.edu.in/Research_Publications. html). Swami Vivekananda Yoga Anusandhana Samsathana (S-VYASA), established in 1986, is a pioneer Institute in the field of Yoga Research. It is the first and foremost Institute with a broad vision of scientifically evaluating yoga, its applications, and policies led by Dr. H R Nagendra (4).

A tremendous increase in Yoga participation has been reported in the US since 2005 . About 30 million people perform Yoga daily to get health benefits $(5,6)$. The increased global interest in Yoga in recent decades could be based on the health-promoting benefits of Yoga. Yoga therapy is evolving rapidly and advocated as a safe and effective intervention by National Health Services (UK) and National Institutes of Health (US) (7-13). A continuous rise in Yoga schools and practitioners is also evident across the globe (5). The science of Yoga and the underlying technology of this mind-body medicine need a more thorough investigation through carefully designed mechanistic and clinical studies. There are many challenges and barriers that hinder the realization of the optimal potential of Yoga in education and Research (14). For example, the current understanding of Yoga is limited as a behavioral therapy or lifestyle intervention (14). Barriers to the practice of Yoga and the knowledge gap in its understanding also serve as the key determinants of the success of Yoga for its successful implementation as public health administration as well as its practical acceptance in the academic sector. Modern lifestyle, occupational pressure, family commitments are a few suggested barriers for Yoga Practice (9).

Many Western medical schools viz. Columbia University, Harvard University, Johns Hopkins University, University of California, Stanford University, and research centers in Europe have rapidly developed centers of excellence in Mind-Body medicine. However there is a lack of active participation of many of the corresponding premier Indian Institutions and Universities. There is an urgent need to evaluate the perceptions and barriers as perceived by the Institutions of National Eminence and their Ethical and Academic committees that belong to the Indian scientific and academic community for successful evaluation of Yoga-based research and educational programs. This can provide a necessary policy framework for evidence-based decisions for Yoga research, barrier and benefits of Yogic practices and identify the knowledge gap in the research and health care fraternity. There is a need to develop policies that promote the participation of the Indian Institutions and Universities that have not shown their active participation in Yoga research so far. An evaluation of Institutions that have been ranked highest in MHRD's National Institutional Ranking Framework (NIRF) (https://www.nirfindia.org/Home) provides a framework to methodologically rank Institutions across the country driven by the overall recommendations by a Core Committee set up by MHRD. This process can aim to assess the performance of the Institutions based on broad parameters that cover "Teaching,
Learning and Resources," "Research and Professional Practices," "Graduation Outcomes," "Outreach and Inclusivity," and "Perception". The active participation of Institutes with high NIRF rankings and inclusion assessment of AYUSH programs in such Institutions along with their Ethical committees would trigger changes that may lead to the adoption of Integrative medicine in such Institutes and utilize the public health potential of AYUSH research conducted since the launch of Ministry of AYUSH. Until new publication characterized by biomarker, animal models and cell culture studies have dominated the life science ranking (15-33).

\section{References}

1. Certification of yoga professionals guide book, Ministry of AYUSH, Government of India, 2016.

2. Bhattacharyya A, Patil NJ, Muninarayana C. "Yoga for promotion of health": conference held on International day of yoga-2015 at Kolar. Journal of Ayurveda and integrative medicine. 2015 Oct;6(4):305.

3. Marques CS, Ferreira J, Rodrigues RG, Ferreira M. The contribution of yoga to the entrepreneurial potential of university students: a SEM approach. International Entrepreneurship and Management Journal. 2011 Jun 1;7(2):255-78.

4. Nagendra HR, Anand A. Indian PM's evidence based wellness approach inspires politico-scientific activism. Annals of Neurosciences. 2019; 26(1):3.

5. McCall MC. In search of yoga: Research trends in a western medical database. Int J Yoga. 2014;7(1):4-8.

6. Birdee GS, Legedza AT, Saper RB, Bertisch SM, Eisenberg DM, Phillips RS Characteristics of yoga users: results of a national survey. Journal of General Internal Medicine. 2008 Oct 1;23(10):1653-8.

7. Hoyez AC. The 'world of yoga': the production and reproduction of therapeutic landscapes. Soc Sci Med. 2007 Jul;65(1):112-24.

8. Dayananda H, Ilavarasu JV, Rajesh S, Babu N. Barriers in the path of yoga practice: An online survey. Int J Yoga. 2014;7(1):66-71.

9. Chu P, Gotink RA, Yeh GY, Goldie SJ, Hunink MM. The effectiveness of yoga in modifying risk factors for cardiovascular disease and metabolic syndrome: A systematic review and meta-analysis of randomized controlled trials. European journal of preventive cardiology. 2016 Feb;23(3):291-307.

10. Aljasir B, Bryson M, Al-shehri B. Yoga practice for the management of type II diabetes mellitus in adults: a systematic review. Evidence-Based Complementary and Alternative Medicine. 2010;7(4):399-408.

11. Posadzki P, Ernst E. Yoga for asthma? A systematic review of randomized clinical trials. Journal of Asthma. 2011 Aug 1;48(6):632-9.

12. Kirkwood G, Rampes H, Tuffrey V, Richardson J, Pilkington K. Yoga for anxiety: a systematic review of the research evidence. British journal of sports medicine. 2005 Dec 1;39(12):884-91.

13. Tabish SA. Complementary and Alternative Healthcare: Is it Evidencebased? Int J Health Sci (Qassim). 2008;2(1):5-9.

14. Mutalik G, Tillu G, Patwardhan B. AyurYoga, the confluence of healing sciences: A call for global action. J Ayurveda Integr Med. 2019;10(2): 79-80.

15. Sharma NK, Gupta A, Prabhakar S, Singh R, Bhatt AK, Anand A. CC chemokine receptor-3 as new target for age-related macular degeneration. Gene. 2013 Jul 1;523(1):106-11.

16. Anand A, Banik A, Thakur K, L Masters C. The animal models of dementia and Alzheimer's disease for pre-clinical testing and clinical translation. Current Alzheimer Research. 2012 Nov 1;9(9):1010-29.

17. Anand A, Gupta PK, Sharma NK, Prabhakar S. Soluble VEGFR1 (sVEGFR1) as a novel marker of amyotrophic lateral sclerosis (ALS) in the North Indian ALS patients. European Journal of Neurology. 2012 May;19(5):788-92. 
18. Goyal K, Koul V, Singh Y, Anand A. Targeted drug delivery to central nervous system (CNS) for the treatment of neurodegenerative disorders: trends and advances. Central Nervous System Agents in Medicinal Chemistry (Formerly Current Medicinal Chemistry-Central Nervous System Agents). 2014 Apr 1;14(1):43-59.

19. Kamal Sharma N, Gupta A, Prabhakar S, Singh R, Sharma S, Anand A. Single nucleotide polymorphism and serum levels of VEGFR2 are associated with age related macular degeneration. Current neurovascular research. 2012 Nov 1;9(4):256-65.

20. Anand A, Saraf MK, Prabhakar S. Sustained inhibition of brotizolam induced anterograde amnesia by norharmane and retrograde amnesia by l-glutamic acid in mice. Behavioural brain research. 2007 Aug 22;182(1):12-20.

21. Anand A, Saraf MK, Prabhakar S. Antiamnesic effect of B. monniera on L-NNA induced amnesia involves calmodulin. Neurochemical research. 2010 Aug 1;35(8):1172-81.

22. Singh T, Prabhakar S, Gupta A, Anand A. Recruitment of stem cells into the injured retina after laser injury. Stem cells and development. 2012 Feb 10;21(3):448-54.

23. Gupta PK, Prabhakar S, Abburi C, Sharma NK, Anand A. Vascular endothelial growth factor-A and chemokine ligand (CCL2) genes are upregulated in peripheral blood mononuclear cells in Indian amyotrophic lateral sclerosis patients. Journal of neuroinflammation. 2011 Dec 1; 8(1):114.

24. Vinish M, Prabhakar S, Khullar M, Verma I, Anand A. Genetic screening reveals high frequency of PARK2 mutations and reduced Parkin expression conferring risk for Parkinsonism in North West India. Journal of Neurology, Neurosurgery \& Psychiatry. 2010 Feb 1;81(2):166-70.
25. Anand A, Tyagi R, Mohanty M, Goyal M, De Silva KR, Wijekoon N. Dystrophin induced cognitive impairment: mechanisms, models and therapeutic strategies. Annals of neurosciences. 2015 Apr;22(2):108.

26. Banik A, Brown RE, Bamburg J, Lahiri DK, Khurana D, Friedland RP, Chen W, Ding Y, Mudher A, Padjen AL, Mukaetova-Ladinska E. Translation of Pre-Clinical Studies into Successful Clinical Trials for Alzheimer's Disease: What are the Roadblocks and How Can They Be Overcome? 1. Journal of Alzheimer's Disease. 2015 Jan 1;47(4):815-43.

27. Anand A, Sharma NK, Gupta A, Prabhakar S, Sharma SK, Singh R, Gupta PK Single nucleotide polymorphisms in MCP-1 and its receptor are associated with the risk of age related macular degeneration. PloS one. 2012 Nov 21;7(11):e49905.

28. Sharma K, Sharma NK, Anand A. Why AMD is a disease of ageing and not of development: mechanisms and insights. Frontiers in aging neuroscience. 2014 Jul 10;6:151.

29. Sharma NK, Gupta A, Prabhakar S, Singh R, Sharma SK, Chen W, Anand A. Association between $\mathrm{CFH}$ Y402H polymorphism and age related macular degeneration in North Indian cohort. PloS one. 2013 Jul 29;8(7):e70193.

30. Mathur D, Goyal K, Koul V, Anand A. The molecular links of re-emerging therapy: a review of evidence of Brahmi (Bacopa monniera). Frontiers in pharmacology. 2016 Mar 4;7:44.

31. Anand A, Thakur K, Gupta PK. ALS and oxidative stress: the neurovascular scenario. Oxidative medicine and cellular longevity. 2013 Oct;2013.

32. English D, Sharma NK, Sharma K, Anand A. Neural stem cells-trends and advances. Journal of cellular biochemistry. 2013 Apr;114(4):764-72.

33. Sharma NK, Prabhakar S, Gupta A, Singh R, Gupta PK, Gupta PK, Anand A. New biomarker for neovascular age-related macular degeneration: eotaxin-2. DNA and cell biology. 2012 Nov 1;31(11):1618-27.

doi: 10.38205/imcr.020101 